\title{
Induced Immune Response of Escherichia coli BL21 Expressing Recombinant MSP1a and MSP1b Proteins of Anaplasma marginale
}

\author{
Katia Tamekuni ${ }^{1}$, Marilda Carlos Vidotto ${ }^{1}$, Samuel Rodrigues Felix ${ }^{2}$, Michelle Igarashi ${ }^{1}$, \\ João Luis Garcia ${ }^{1}$, Adriana Letícia Coelho ${ }^{1}$, Marcela Ribeiro Gasparini ${ }^{1}$, Elizabete Regina \\ Marangoni Marana ${ }^{1}$, Sérgio Silva da Silva ${ }^{2}$ and Odilon Vidotto ${ }^{1 *}$ \\ ${ }^{I}$ Departamento de Medicina Veterinária Preventiva; Centro de Ciências Agrárias; Universidade Estadual de \\ Londrina; Pr 445 km 380; C. P.: 6001; 86051-970; Londrina - PR - Brasil. ${ }^{2}$ Departamento de Veterinária \\ Preventiva; Faculdade de Veterinária; Universidade Federal de Pelotas; Pelotas - RS - Brasil
}

\begin{abstract}
This work aims to evaluate the potential of immunization with E. coli BL21 expressing the recombinant rMSP1a and rMSP1b proteins of Anaplasma marginale. E. coli BL21 was transformed with recombinant plasmids pET102/mspl $\alpha$ and pET101/mspl $\beta$, and rMSPIa and rMSP1b were expressed after induction by IPTG. BALB/c mice were vaccinated with formolized BL21/rMSP1a and BL21/rMSP1b, and the production in mice sera of whole IgG was determined by ELISA. The mice immunized with BL21/rMSPla showed a better humoral response for whole IgG when compared to the mice immunized with BL21/rMSP1b; these mice exhibited a small response after the second vaccination. Sera of mice immunized with BL21/rMSP1a reacted via western blot with BL21 and rMSP1a, with molecular masses varying from 70 to $105 \mathrm{kDa}$. Sera of mice immunized with BL21/rMSP1b reacted with BL21 and rMSP1b with a molecular mass of $100 \mathrm{kDa}$. These results demonstrate that BL21 containing rMSPla and $r M S P 1 b$ in the outer membrane were able to produce an immune response in mice, reinforcing its use in vaccine models against bovine anaplasmosis.
\end{abstract}

Key words: Anaplasma marginale, MSP1a, MSp1b, vaccine, mice, cattle

\section{INTRODUCTION}

Anaplasma marginale, an obligate intraerythrocytic pathogen belonging to the Anaplasmataceae family of the Rickettsiales order (Dumler et al., 2001), is the causative agent of bovine anaplasmosis worldwide, especially in tropical and subtropical regions, causing severe losses in bovine livestock (Richey and Palmer, 1990).

Immunization with purified outer membranes induces protection against acute A. marginale infection and disease (Tebele et al., 1991). Some well-characterized outer membrane proteins, designated major surface proteins (MSPs), MSP1a, MSP1b, MSP2, MSP3, MSP4, MSP5, and recently VirB9 and VirB10, have been evaluated as

* Author for correspondence: vidotto@uel.br 
potential candidates for antigens in vaccine production, diagnostic evaluation, and determination of intermolecular relationships (Palmer and McElwain, 1995; Lopez et al., 2007; Vidotto et al., 1994, 2008).

The proteins MSP1a (105 kDa) and MSP1b (100 $\mathrm{kDa}$ ) form the MSP1 complex, and both proteins have been identified as putative adhesins for bovine erythrocytes (McGarey et al., 1994; Palmer et al., 1987; McGarey and Allred, 1994). The protein MSP1a is an A. marginale adhesin for both bovine erythrocytes and tick cells, while MSP1b is an adhesin for bovine erythrocytes only (de la Fuente et al., 2001).

MSP1a is encoded by a single mspl $\alpha$ gene in all $A$. marginale strains, and MSP1b by a multigene family (mspl 131 and $m s p 1 \beta 2$ ), which manifests a small variation in MSP1b1 and MSP1b2 sequences during the multiplication phases in cattle and tick cells (Oberle et al., 1988). MSP1a is composed of a highly conserved C-terminal region and an $\mathrm{N}$-terminal region consisting of 28 or 29 amino acid repeats that vary in number and sequences and which are responsible for variable molecular mass among A. marginale strains (Allred et al., 1990; Oberle et al., 1993). Despite variation in the $\mathrm{N}$-terminal regions, all strains contain a conserved neutralization-sensitive epitope defined by monoclonal antibodies (Palmer et al., 1987; Allred et al., 1990; Kano et al., 2002). The protein complex MSP1 induces intense proliferation of mononuclear cells of peripheral blood and $\mathrm{CD} 4^{+}$T-cells in cattle inoculated with homologous and heterologous isolates of $A$. marginale (Palmer et al., 1989; Brown et al., 2001). The proliferation of mononuclear cells is related to the participation of conserved T-cell epitopes, localized on the C extremity of MSP1a, which stimulates elevated levels of interferon $\gamma$. A weak cellular immune response has been seen against MSP1b, while an intense humoral response has been observed with MSP1a and MSP1b (Brown et al., 2001, 2002).

Vaccination can be an economic alternative for the control of bovine anaplasmosis; however, the current commercialized $A$. centrale live vaccines present limitations in protecting animals against heterologous isolates of $A$. marginale and frequently cause isoerythrolysis in calves due to colostral antibody transfer (Kuttler et al., 1984). Furthermore, live vaccines can potentially transmit blood-borne pathogens (such as viruses, bacteria, and protozoa) among animals in cattle herds
(Palmer et al., 1989; Kocan et al., 2000).

The aim of this work was to evaluate the immune response in mice immunized with recombinant $E$. coli expressing A. marginale MSP1a and MSP1b.

\section{MATERIALS AND METHODS}

\section{Production of r-MSP1a and r-MSP1b on E. coli} Recombinant E. coli strains were obtained as previously described (Tamekuni et al., 2009). The $E$. coli BL21 (D3) strain was transformed with the recombinant plasmids pET102/msp $1 \alpha$ and pET101/msp $1 \beta$, and the recombinant strains were grown to an optical density of $\mathrm{OD}_{600 \mathrm{~nm}} 0.8$. IPTG (isopropyl-1- $\quad \beta-\quad D-\quad$ thiogalactopyranoside) (Invitrogen Life Technologies, USA) was then added to $1 \mathrm{mM}$ and incubated for $4 \mathrm{~h}$. An aliquot of culture was removed, the cells were collected by centrifugation and the expression of proteins analyzed on SDS-PAGE $10 \%$.

To obtain rMSPs purification, BL21/ pET102/msp $1 \alpha$ and pET101/msp $1 \beta$ strain was grown with IPTG for $4 \mathrm{~h}$ at $37^{\circ} \mathrm{C}$. The cells were collected by centrifugation and incubated with lysis buffer, and rMSP1a and rMSP1b were purified using Ni-NTA columns (Qiagen Biotecnologia Brasil Ltda). The rMSP1a and rMSP1b strains were dialyzed and measured using the Bradford method and analyzed on SDS-PAGE $10 \%$.

\section{Immunization of BALB/c mice}

To assess the acquired humoral immune response against whole bacteria expressing rMSP1a and rMSP1b, 4- to 5-week-old mice were immunized with formalin-inactivated recombinant $E$. coli. Formalin-killed bacteria were obtained by growing in LB with IPTG for $4 \mathrm{~h}$ at $37^{\circ} \mathrm{C}$, titering to determine CFUs, resuspending in $1 \%$ formalin in 1X PBS and subsequently incubating at $37{ }^{\circ} \mathrm{C}$ for $24 \mathrm{~h}$. The killed bacteria were washed with sterile PBS ( $\mathrm{pH}$ 7.2) and resuspended in PBS for a final concentration of $1 \times 10^{9} \mathrm{CFU}$.

Six groups of seven female BALB/c mice were immunized with BL21/rMSP1a and BL21/rMSP1b to produce immune sera. The negative control group 1 (G1) received $100 \mu \mathrm{L}$ of PBS; group 2 (G2) was immunized with $100 \mu \mathrm{g}$ of protein from initial bodies of A. marginale PR1 isolate, obtained as previously described (Vidotto et al., 1994). Other groups were immunized as follows: 
group 3 (G3) with $10^{9} \mathrm{CFU}$ of $E$. coli BL21/rMSP1a; group 4 (G4) with $10^{9} \mathrm{CFU}$ of $E$. coli BL21/rMSP1b; group 5 (G5) with $10^{9} \mathrm{CFU}$ of E. coli $\mathrm{BL} 21 / \mathrm{rMSP} 1 \mathrm{a}$ and $E$. coli $\mathrm{BL} 21 / \mathrm{rMSP} 1 \mathrm{~b}$; and group 6 (G6) with $10^{9}$ CFU of E. coli BL21. Vaccinations were carried out by subcutaneous injection at 0,7 and 14 days. The recombinant bacteria and initial bodies of $A$. marginale were emulsified with complete Freund's adjuvant (Sigma-Aldrich, Brasil) in the first vaccination and with incomplete Freund's adjuvant (SigmaAldrich, Brasil) in subsequent vaccinations. After each inoculation, the animals were bled, the sera were separated and the titer and specificity of antibodies were analyzed by enzymeimmunoassay (ELISA) and western blot. Serum control was obtained from non-immunized animals.

\section{Evaluation of antibody response by indirect ELISA}

Optimal dilutions were established using checkerboard titrations with dilutions of sera, antigen and conjugates. The anti-A. marginale antibody response at $0,7,21$ and 35 days was evaluated using $A$. marginale antigens (initial bodies) to coat wells in a 96-well microtiter plate (NUNC MaxiSorp ${ }^{\mathrm{TM}}$, California, USA) at 0.5 $\mu \mathrm{g} /$ well. After overnight incubation at $4{ }^{\circ} \mathrm{C}$, serum samples from each group of immunized mice were diluted to 1:50 in PBST buffer and $\mathrm{pH}$ adjusted to 7.4 with $5 \%$ skimmed powder milk. Then, $100 \mu \mathrm{L}$ of the diluted sample were added in duplicate to each well and incubated for $45 \mathrm{~min}$ at $37^{\circ} \mathrm{C}$. After three washes, anti-mouse $\operatorname{IgG}$ conjugated with horseradish peroxidase conjugate $(1: 10.000)$ was added and incubated for $45 \mathrm{~min}$ at $37{ }^{\circ} \mathrm{C}$. The substrate for enzyme detection was OPD (ophenylenediamine) $0.4 \mathrm{mg} / \mathrm{mL}, \mathrm{H}_{2} \mathrm{O}_{2} 0.04 \%$ in substrate buffer $(0.1 \mathrm{M}$ acid citric, $0.2 \mathrm{M}$ $\mathrm{Na}_{2} \mathrm{HPO}_{4}$ ). The reaction was then blocked with 50 $\mu \mathrm{L}$ of $1 \mathrm{M} \mathrm{HCl}$ and the plates read at $490 \mathrm{~nm}$. The absorbance values were estimated and the optical density (OD) value was obtained. The corrected ODs for G3, G4, and G5 were calculated using the OD mean of G6 to subtract the background of BL21, as follows: $\mathrm{OD}_{\text {corr }}=\left(\mathrm{OD}\right.$ sample ${ }_{(\mathrm{G} 3, \mathrm{G} 4}$, or G5) - $\mathrm{OD}_{\text {average }}$ of $\mathrm{G6}$ for each day $(0,7,21$ or 35$)$ ).

\section{SDS PAGE and western blot}

The purified rMSP1a and rMSP1b proteins were suspended in electrophoresis sample buffer $(0.025$ $\mathrm{M}$ Tris $\mathrm{HCl}, 2 \%$ SDS, $15 \%$ glycerol, 2.5\% 2mercaptoethanol, $\mathrm{pH}$ 6.8), boiled for $5 \mathrm{~min}$ and electrophoresed in SDS-PAGE-10\%. Mass molecular standard was used (Multimarck, Invitrogen). Gels were either stained with Coomassie blue or set up for western blot. The proteins were transferred to a $0.45-\mu \mathrm{m}$ nitrocellulose membrane (Amersham Biosciences do Brasil Ltda), as described previously (Towbin and Gordon, 1984). The membranes were blocked in blocking buffer (PBS with $0.1 \%$ Tween 20 and $5 \%$ non-fat powdered milk) for $1 \mathrm{~h}$ at room temperature under agitation. Membranes were washed in PBST (PBS with 0.1\% Tween 20) and incubated for $1 \mathrm{~h}$ with a pool of sera from each group, obtained from mice bled at day 35 , and a pool of pre-immune sera at 1:100 dilution. The membranes were washed, and the proteins were detected by means of enhanced chemiluminescence (ECL) western blot system (Amersham Biosciences do Brasil Ltda). Protein molecular weight markers (Rainbow ${ }^{\mathrm{TM}}$ colored, Amersham Biosciences do Brasil Ltda) were used as standards.

\section{Bioethics in animal experimentation}

The animals were kept according to the National Institute of Health standards for the use of laboratory animals. The experiments were approved by the Ethics Committee in Animal Experimentation of the Universidade Estadual de Londrina (CEEA 47/05, process 26957/05).

\section{RESULTS}

The whole IgG production in mice during the trial is shown at Fig 1, representing sera from BALB/c mice at $0,7,21$, and 35 days after initial immunization. All pre-immunized sera and negative control group sera $(\mathrm{G} 1)$ reacted below $\mathrm{OD}=0.092$. Mouse sera from the group immunized with $A$. marginale (G2) exhibited seroconversion $\left(\mathrm{OD}_{\text {mean }}=0.305\right.$, day 7$)$ after the first immunization, and this rate increased 
throughout the experiment $\left(\mathrm{OD}_{\text {mean }}=0.463\right.$, day 21 , and $\mathrm{OD}_{\text {mean }}=0.615$, day 35). In G3 and G5, high antibody responses were obtained after the second immunization $\left(\mathrm{OD}_{\text {corr }} \mathrm{G} 3=0.309,0.339\right.$, Western blot results using a pool of mouse sera, rMSP1a and rMSP1b strains of A. marginale and E. coli BL21 are shown in Fig 2. The preimmunized and post-immunized sera of mice from G1 (PBS) (Fig 2) only reacted to an unspecific band of protein smaller than $100 \mathrm{kDa}$. Sera from mice immunized with A. marginale initial bodies (G2) reacted to all native MSPs (approximately 100, 76, 38, $31 \mathrm{kDa}$ proteins) (Fig 2). Sera from mice immunized with BL21/rMSP1a (G3) reacted to $100-70 \mathrm{kDa}$ proteins (rMSP1a), while mice immunized with BL21/rMSP1b (G4) reacted to rMSP1b (100 kDa proteins). Mice sera from G5, which received both recombinant bacteria, reacted to rMSP1a and rMSP1b strains of A. marginale and to $E$. coli BL21 proteins, as expected. Mouse sera from G6, which received only E. coli BL21, showed weak reactivity to proteins from this strain (approximately $100 \mathrm{kDa}$ proteins)

\section{DISCUSSION}

The MSP1 complex appears to be essential for bovine erythrocyte $A$. marginale infection and also important for development of a subunit vaccine. Immunization with MSP1 complex confers protection to susceptible cattle against homologous and heterologous A. marginale challenges (Palmer et al., 1989; Brown et al., 2002). However, unlike results obtained with native MSP1a/b complexes, immunization with recombinant MSP1a, MSP1b, or the combination of these two proteins has not induced significant protection (Palmer and McElwain, 1995).

In a previous study, we cloned mspl $\alpha$ and $m s p l \beta$ genes from the PR1 A. marginale strain and the recombinant $E$. coli strains BL21/pET102-mspla and BL21/ pET101-msp $1 \beta$ expressing rMSP1a and rMSP1b on the outer membrane and visualized antibodies produced against rMSP1a and rMSP1b in an IFA (Tamekuni et al., 2009). Also, these recombinant E. coli strains agglutinated bovine erythrocytes, and this agglutination showed the presence of the antibodies anti-rMSP1a and rMSP1b, confirming the adhesive functions of rMSP1a and rMSP1b (Tamekuni et al., 2009) as and $\mathrm{OD}_{\text {corr }} \mathrm{G} 5=0.231,0.258$, mean from days 21 and 35, respectively), while G4 showed seroconversion only after the third immunization $\left(\mathrm{OD}_{\text {corr }} \mathrm{G} 4=0.272\right.$, mean from day 35$)$. previously described (McGarey et al., 1994; Palmer et al., 1987; McGarey and Allred, 1994)

In this study, the mice immunized with recombinant E. coli BL21/pET102-mspl $\alpha$ and BL21/pET101-msp1 $\beta$ showed specific antibody responses to rMSP1a and $\mathrm{rMSP} 1 \mathrm{~b}$ as demonstrated by ELISA (Fig. 1). Also, sera from all mice receiving these bacteria reacted with rMSP1a proteins (70 to $105 \mathrm{kDa}$ ) and rMSP1b proteins (100 kDa) shown in western blot assay (Fig. 2). Thus demonstrates that recombinant E. coli expressing rMSP1a and rMSP1b can induce the production of specific antibodies.

In addition to these data, Kano et al. (2008) recently observed that mice immunized with the association of recombinant plasmids (pcDNAmspl $\alpha$, pcDNA- mspl $\beta$ and pcDNA-msp5) exhibited an intense lymph proliferation when compared to mice immunized with the plasmids alone. Also, the sera from immunized mice reacted with recombinant proteins (rMSP1a, rMSP1b and rMSP5), indicating humoral and cellular response. Our results presented above and the data obtained by Kano et al. (2008) reinforce previous information on immunization with native MSP1 heteromer, which induced strong IgG responses to both proteins. In contrast, only MSP1a stimulated strong $\mathrm{CD} 4+\mathrm{T}$-cell responses and produced a weak cellular immune response against MSP1b (Brown et al., 2001, 2002). Recently, constructs of CD4+ T-cell epitopes from MSP1a linked to MSP1b1 induced higher $\operatorname{IgG}$ titers against MSP1b1 (Macmillan et al., 2008), and this high MSP1b-specific antibody titer in the group immunized with the linked construct was likely due to a higher MSP1b1-to-MSP1a ratio than that in the native MSP1 complex. In the native complex, MSP1a is much more abundant than MSP1b1 (Macmillan et al., 2006).

Protective immunity against $A$. marginale requires stimulation of humoral and cellular mechanisms. Antibodies against the MSP1 facilitate phagocytosis, eliminating A. marginale (Cantor et al., 1993), and they inhibit the invasion of erythrocytes by $A$. marginale (McGarey and Allred, 1994).

Recently, it was verified that the 
ISCOMATRIX/rMSPs vaccine, containing rMSP1a, rMSP1b, rMSP4 and rMSP5 aggregated to ISCOM induced the production of specific antibodies to each of the rMSPs in mice, suggesting that a subunit vaccine containing rMSPs could be efficient against an infection of $A$. marginale (Kawasaki et al., 2007). Therefore, a vaccine with BL21/rMSP1a and BL21/rMSP1b or with outer membrane preparations of these recombinant bacteria could be more easily prepared, considering the difficulty of purifying rMSPs in $\mathrm{Ni}$ columns on a large scale. In conclusion, our results demonstrate that BL21 containing rMSP1a and rMSP1b in the outer membrane were able to produce immune responses in mice, reinforcing its use in vaccine models against bovine anaplasmosis.
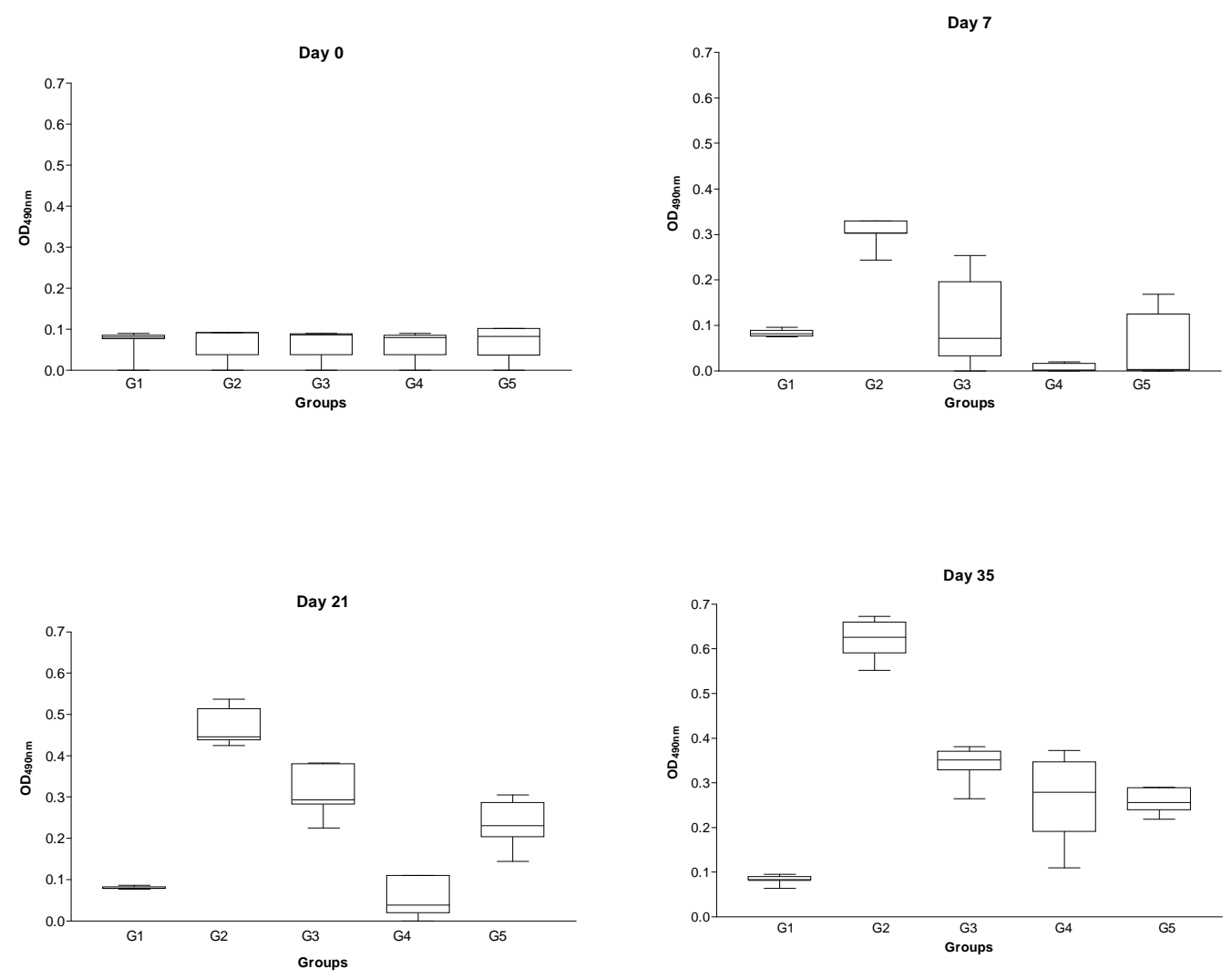

Figure 1 - IgG response (ELISA) of mice immunized with recombinant Escherichia coli BL21, as follows: G1 - negative control (PBS); G2 - positive control (Anaplasma marginale initial bodies); G3 - BL21/rMSP1a; G4 - BL21/rMSP1b; G5 - BL21/rMSP1a + BL21/rMSP1b. The plates of the G1 and G2 were adsorbed with A. marginale initial bodies; G3 with rMSP1a; G4 with rMSP1b; and G5 with rMSP1a + rMSP1b. 


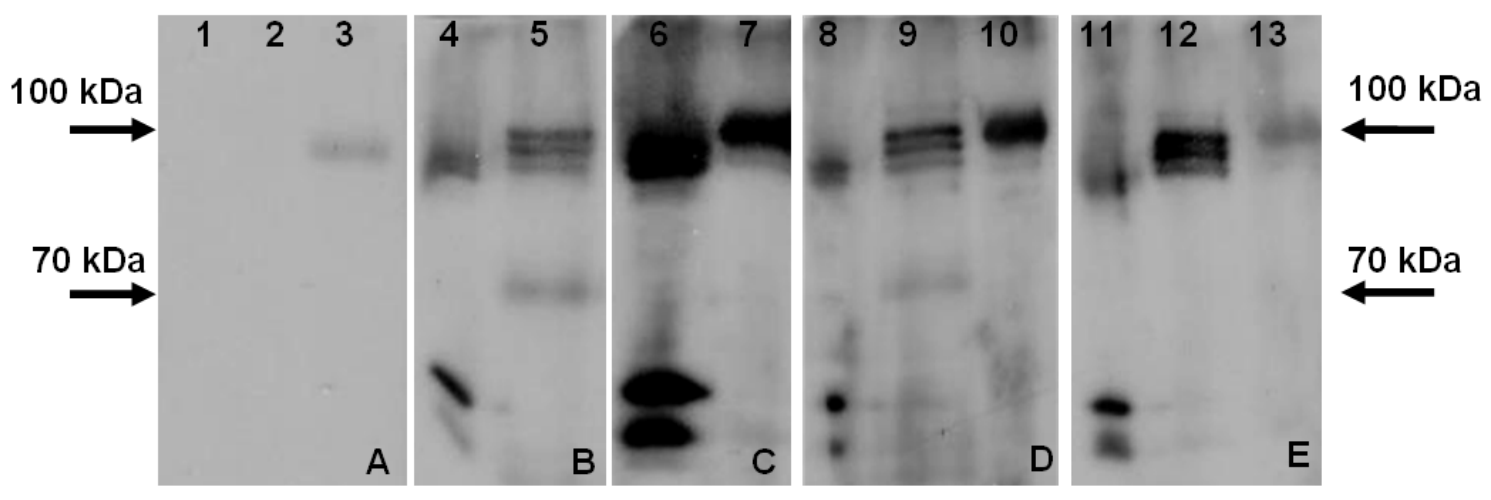

Figure 2 - Western blot with rMSP1a and rMSP1b and sera of mice groups immunized with BL21 and recombinant BL21. Escherichia coli BL21 - lines 1, 4, 6, 8, and 11; rMSP1a lines 2, 5, 9, and 12; rMSP1b - lines 3, 7, 10, and 13. Panel A - Pre-immune pool sera; B - Group 3 pool sera (BL21/rMSP1a); C - Group 4 pool sera (BL21/rMSP1b); D Group 5 sera (BL21/rMSP1a + BL21/rMSP1b); E - Group 2 pool sera (initial bodies of Anaplasma marginale).

\section{ACKNOWLEDGMENTS}

The financial resources for the conduction of this study were supported by the project BioAgroPar financed by FINEP, SETI/PR, and Fundação Araucária/PR; and by CNPq/Brazil.

\section{RESUMO}

Esse trabalho avaliou o potencial de imunização de Escherichia coli BL21 expressando as proteínas recombinantes rMSP1a e rMSP1b de Anaplasma marginale. A E. coli BL21 foi transformada com os plasmídios recombinantes pET102/mspla e pET101/msp1 $\beta$ e as proteínas rMSP1a e rMSP1b foram expressas após indução com IPTG. Camundongos BALB/c foram vacinados com BL21/rMSP1a e BL21/rMSP1b formolisadas, e a produção de $\operatorname{IgG}$ total foi determinada pelo teste de ELISA nos soros dos camundongos imunizados. Os camundongos imunizados com a BL21/rMSP1a mostraram uma melhor resposta humoral para IgG total, comparada à resposta apresentada pelos camundongos imunizados com BL21/rMSP1b; estes camundongos exibiram uma menor resposta após a segunda vacinação. Soros de camundongos imunizados BL21/rMSP1a reagiram pelo western blot com BL21 e rMSP1a, com massa molecular variando de 70 a $105 \mathrm{kDa}$. Soro de camundongos imunizados com BL21/rMSP1b reagiram com BL21 e rMSP1b com massa molecular de $100 \mathrm{kDa}$. Esses resultados demonstram que BL21 contendo rMSP1a e rMSP1b na membrana externa foram capazes de produzir resposta imune em camundongos, reforçando o seu uso em modelos de vacina contra a anaplasmose bovina.

\section{REFERENCES}

Allred, D. R., Palmer, G. H., McGuire, T. C., Leib, S. D., Harkins T. M., McElwain, T. E., Barnet, A. E., (1990), Molecular basis for surface antigen size polymorphisms and conservation of a neutralizationsensive epitope in Anaplasma marginale. Proceedings of National of Academy Science, 87, 3220-3224.

Brown, W., Shkap, V., Zhu, D., McGuire, T. C., Tuo, W., McElwain, T. F., Palmer, G. H., (1998), CD4 ${ }^{+}$TLymphocyte and Immunoglobulin G2 Responses in Calves Immunized with Anaplasma marginale Outer Membranes and Protected against Homologous Challenge. Infec. Immun., 66, 5406-5413. 
Brown, W., Palmer, G. H., Lewin, H. A., McGuire, T. C., (2001), CD4+ T Lymphocytes from calves immunized with Anaplasma marginale major surface protein 1 (MSP1), a heteromeric complex of MSP1a and MSP1b, preferentially recognize the MSP1a carboxyl terminus that is conserved among strains. Infec. Immun., 69, 6853-6862.

Brown, W., McGuire, T. C., Mwangi, W., Kegerreis, K. A., Macmillan, H., Lewin, H. A., Palmer, G. H., (2002), Major Histocompatibility complex Class II DR- Restricted Memory CD4+ T Lymphocytes Recognize Conserved Immunodominant Epitopes of Anaplasma marginale Major Surface Protein 1a. Infec. Immun. 70, 5521-5532.

de la Fuente, J., Garcia-Garcia, J. C., Blouin, E. F., Kocan, K. M., (2001), Differential adhesion of major surface proteins $1 \mathrm{a}$ and $1 \mathrm{~b}$ of the ehrlichial cattle pathogen Anaplasma marginale to bovine erythrocytes and tick cells. Intern. J. Parasitol., 31, 145-153.

Cantor, G. H., Pontzer, C. H., Palmer, G. H., (1993), Opsonization of Anaplasma marginale mediated by bovine antibody against surface protein MSP-1. Vet. Immunol. Immunophatol., 37, 343-350.

Dumler, J. S., Barbet, A. F., Bekker, C. P. J., Dasch, G. A., Palmer, G. H., Ray, S. T., Rikihisa, Y., Rurangirwa, F. R., (2001), Reorganization of genera in families Rickettsiaceae and Anaplasmataceae in the order Rickettsiales: unification of some species of Ehrlichia with Anaplasma, Cowdria with Ehrlichia with Neorickettsia, descriptions of six new species combinations and designation of Ehrlichia equi and "EGH agent" as subjective synonyms of Ehrlichia phagocytophila. Int. J. Syst. Evol. Microbiol., 51, 2145-2165.

Kano, F.; Vidotto, O.; Pacheco, R. C.; Vidotto, M. C., (2002), Antigenic characterization of Anaplasma marginale isolates from different regions of Brazil. Vet. Microbiol., 87, 131-138.

Kano, F. S., Tamekuni, K., Coelho, A. L., Garcia, J. L., Vidotto, O., Itano, E. N., Vidotto, M. C., (2008), Induced immune response of DNA vaccine encoding an association MSP1a, MSP1b, and MSP5 antigens of Anaplasma marginale. Vaccine, 26, 3522-3527.

Kawasaki, P. M., Kano, F. S., Tamekuni, K., Garcia, J. L., Marana, E. R., Vidotto, O., Vidotto, M. C., (2007), Immune response of BALB/C mouse immunized with recombinant MSPs proteins of Anaplasma marginale binding to immunostimulant complex (ISCOM). Res. Vet. Sci., 83, 347-354.

Kocan, K.M., Blouin, E.F., Barbet, A.F., 2000. Anaplasmosis control: past, present and future. Ann. N. Y. Acad. Sci. 916, 501-509.
Kuttler, K. L., Zaugg J. L., Johnson, L. W., (1984), Serologic and clinical responses of premunized vaccinated and previously infected cattle to challenge exposure by two different Anaplasma marginale. Am. J. Vet. Res., 45, 2233-2240.

Lopez J. E., Palmer, G. H., Brayton, K. A., Dark, M. J., Leach, S. E., Brown, W.C., (2007), Immunogenicity of Anaplasma marginale type IV secretion system proteins in a protective outer membrane vaccine. Infec. Immun.,75, 2333-2342.

McGarey, D. J., Allred, D. R., (1994), Characterization of hemagglutinating components on the Anaplasma marginale initial body surface and identification of possible adhesins. Infec. Immun., 62, 4587-4593.

McGarey, D.J., Barbet, A.F., Palmer, G.H., McGuire, T.C., Allred, D.R., 1994. Putative adhesins of Anaplasma marginale: major surface polypeptides 1a and 1b. Infec. Immun. 62, 4594-4601.

Macmillan, H., Brayton, K. A., Palmer, G. H.; McGuire, T. C., Munske, G., Siems, W. F., Brown, W.C., (2006), Analysis of the Anaplasma marginale Major Surface Protein 1 Complex Protein Composition by Tandem Mass Spectrometry. $J$. Bacteriol., 188, 4983-4991.

Macmillan, H., Norimine, J, Brayton, K. A., Palmer, G. H., Brown, W. C., (2008), Physical Linkage of Naturally Complexed Bacterial Outer Membrane Proteins Enhances Immunogenicity. Infec. Immun., 76, 1223-1229.

Orbele, S. M., Palmer, G. H., Barbet, A. F., McGuire, T. C., (1988), Molecular size variation in an immunoprotective protein complex among isolates of Anaplasma marginale. Infec. Immun.. 56, 1567-1573.

Orbele, S. M., Palmer, G. H., Barbet, A. F., (1993), Expression and immune recognition of the conserve MSP4 outer membrane protein of Anaplasma marginale. Infec. Immun., 61 (12), 5245-5251.

Palmer, G. H., Waghela, S. D., Barbet, A. F., Davis, W. C., McGuire, T. C., (1987), Characterization of a neutralization sensitive epitope on the Am 105 surface protein of Anaplasma marginale. Int. J. Parasitol., 17, 1279-1285.

Palmer, G. H., Barbet, A. F., Cantor, G. H., McGuire, T. C., (1989), Immunization of cattle with the MSP-1 surface protein complex induces protection against a structurally variant Anaplasma marginale isolate. Infec. Immun., 57, 3666-3669.

Palmer, G. H., McElwain, T. F., (1995), Molecular basis for vaccine development against anaplasmosis and babesiosis. Vet. Parasitol., 57, 233-253.

Richey, E. J., Palmer, G. H., (1990), Bovine Anaplasmosis. Continuing Education Article, 10 (12), 1661-1668. 
Tamekuni, K., Kano, F. S., Ataliba, A. C., Marana, E. R. M., Venancio, E. J., Vidotto M. C., Headley, S. A., Vidotto, O., (2009), Cloning, expression and characterization of the MSP1a and MSP1b recombinant proteins from PR1 Anaplasma marginale strain, Brazil. Res. Vet. Sci., 86, 98-107.

Tebele, N., McGuire, T. C., Palmer, G. H., (1991), Induction of protective immunity using Anaplasma marginale initial body membranes. Infec. Immun., 59, 3199-3204.
Vidotto, M. C., McGuire, T. C., McElwain, T. F., Palmer, G. H., Knowles, D. P., (1994), Intermolecular relationships of major surface protein of Anaplasma marginale. Infec. Immun., 62, 2940-2946.

Vidotto, M. C., Venancio, E. J., Vidotto, O., (2008), Cloning, sequencing and antigenic characterization of rVirB9 of Anaplasma marginale isolated from Paraná State, Brazil. Gen. Mol. Res., 7, 460-466. 